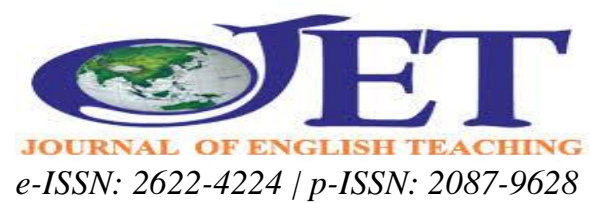

\title{
Learning Vocabularies Using Short Stories at Primary School: Students' Perception
}

\author{
Pitriani Nazara \\ pitryanynaz@gmail.com \\ Global Sevilla Primary School, Jakarta, Indonesia
}

DOI: http://dx.doi.org/10.33541/jet.v5i3.1308

\begin{abstract}
Various studies have shown that using short stories in language teaching is very advantageous because it provides authentic material, cultural enrichment, language advancement, and personal growth. Among the various literary genres, a short story is one of the most appropriate to use in a language classroom. This study was conducted to investigate the perception of primary school students to develop vocabulary. Employed a mixed methods research design, quantitative and qualitative data were collected from 30 sixth graders at Global Sevilla Primary School Jakarta. The quantitative data was collected using a questionnaire, and the qualitative data was gathered through interviews. The data obtained were descriptively analyzed employing SPSS and Excel. The results showed that the students' perception towards the use of short story was positive. For them, short stories were interesting materials to use to develop vocabulary. Based on findings, short stories are recommended to use to develop students' vocabulary.
\end{abstract}

Keywords: perception, short stories, vocabulary learning,

\section{INTRODUCTION}

Vocabulary is the most important component of language teaching for young learners. The teaching of English vocabulary, therefore, has a very essential role to enable English as a foreign language (EFL) students to master English. According to Richard and Rodgers (2001), vocabulary is one of the important elements of language proficiency for it is the basis of how well learners speak, write, listen and read. Without a good mastery of vocabulary, learners may be discouraged in using the language being learned in daily activities. Thornbury (2005) highlighted that vocabulary holds a crucial position in English. Vocabulary, which is defined by Hornby (2000) as all the words in a particular language or "A list or collection of words and phrases usually alphabetically arranged and explained or define" (Merriam, 2003), is the main element of language used to inform, to express ideas, to reveal desire and feeling, and to communicate with others. Hammer (2002) accentuated that, "without grammar very little can be conveyed, without vocabulary, nothing can be conveyed." It means that vocabulary is the main element in communication. 


\section{Vocabulary Teaching}

As the main element of communication, vocabulary is an important aspect of English language learning. If the students do not have any vocabulary, it will be difficult for them to communicate with each other. Similarly, Wallace (2007) believes that vocabulary has an important key in learning English. Therefore, vocabulary acquisition is one of the central components of developing successful communication and literacy skills. Students can use vocabulary as they listen, speak, read and write. Students learn vocabulary directly and indirectly. They can reveal their ideas and comprehend other people's ideas if they have good vocabulary mastery. According to Thombury (2004), teaching vocabulary means conveying new information into the already existing system of the mental lexicon.

Realizing the importance of vocabulary in communication and language learning as well, helping students to acquire a wide range of vocabulary is indispensable for any language teaching program. What is more, vocabulary learning is considered as a difficult task for foreign language learners (Mccarthy \& O'Dell, 2002). Thus, Thombury (2004) recommended that teaching vocabulary should be made a part of language teaching. The majority of EFL students suffer from a lack of sufficient vocabulary and get frustrated for not having enough words to express their ideas or not knowing the meaning of key vocabulary items in a passage. Accordingly, they find the task of speaking, writing, or reading comprehension so tiresome, laborious and tedious so that they soon give up the task. To assist them not to get frustrated easily and help them enjoy language learning tasks, finding ways to enrich their vocabulary is very important.

Nunan (2003) proposed four principles for teaching vocabulary: First, the teacher should focus on the most useful vocabulary first. Some words can be used in a wide variety of circumstances. Other has much more limited use. Giving priority to teaching useful words before less useful ones gives learners the best return for their learning effort. The most useful words are the ones that every English learner needs for listening, speaking, reading, or writing or whether they use them in formal and informal situations. Second, the teacher should focus on vocabulary in the most appropriate way. This principle concerns with how the learners should be taught and learned. Teachers need to differentiate the way of treating high-frequency words from the way of treating lowfrequency words. Third, the teacher should give attention to the high-frequency words across the four strands of a course. High-frequency vocabulary needs to be used in most parts of a course. It should get deliberate attention through teaching and study and should be met and used in communicating messages in listening, speaking, reading, and writing. High-frequency vocabulary must also be effortlessly accessible for receptive and productive routine. Fourth, the teacher should encourage learners to reflect on and take responsibility for learning. This principle is very important and should become the basis of choosing and learning. Learners should realize that they are responsible for their learning,

\section{Short Story}

Short stories are a work of fiction usually written in prose and narrative format and are shorter in length than a novel. According to Wright (2002), "stories", in a very broad sense, "range from full stories in a book to snippets of behavior", and include "any descriptions of dramatic events in fact or fiction: traditional stories, local legends, contemporary fiction, the news, personal anecdotes, stories made by students...offered through...personal storytelling, television, theatre, cinema, newspapers, public events" 
(p. 1). Since it is relatively short, a short story typically focuses on one central theme, one plot, and one major character (with a few supplementary minor characters), whereas a novel can include various plots and themes, with some prominent characters.

Short stories are an exciting and ever-evolving form of storytelling. They talk about the author's expression to anything about life experience concerning human imagination. As a literary work, short stories are interesting for people to read and talk. They entertain, develop mental experience and develop learners' vocabulary. They are also effective to help English learners practice all the four language skills: reading, writing, listening and speaking (Pardede, 2011).

Using short stories is an effective way to learn vocabulary in EFL It is argued that students who read widely have extensive vocabularies (Blachowicz \& Fisher, 2004). Stories allow the readers to use their imagination to possibly engender new option and hopefully act with foresight. They facilitate the readers to explore their minds of others, as a sort of dress rehearsal for the future (Cron, 2012). This enables short stories to stimulate students to enthusiastically develop their vocabulary to understand the whole story. Learning vocabulary through short stories also helps the teachers create different contexts where students should use the language to communicate, exchange information and express their ideas. Pardede's (2010) study revealed that the majority of English preservice teachers found short stories interesting to use both as materials for self-enjoyment and as the components of language skill classes. In short, short stories are teaching media that can facilitate the students to learn more about vocabulary.

Al-Dersi (2013) listed several strengths of short story use in language learning. First, a short story makes learning English an enjoyable and attractive process for learners. Second, a short story stimulates learners' curiosity about the target culture and language. Third, the short story encourages language acquisition and the learners' language awareness. Fourth, a short story offers new words with the actual usage in many forms, thus learners can understand the meaning and the usage in the context of the new words. Fifth, the short story makes the readers guess what would happen next and therefore involve them in that process actively and help them understand the meaning of new words they encounter through context. Sixth, a short story offers opportunities for EFL teachers to integrate them with productive skills like speaking and writing. Seventh, the short story makes the students can bring it everywhere; it does not need much time to read it. Eighth, creative opportunities: it encourages the students to be creative students. From the statements above, it can be concluded that the short story technique has many advantages, such as increasing vocabulary, enjoyable method, offers the usage in context, and not consuming much time. Brabham \& Villaume (2002) asserted that a thoughtful assurance to reducing gaps in vocabulary and comprehension includes instruction allowing all students to learn and use strategies that will enable them to discover and develop understandings of words throughout the independent reading.

Besides its strength, the short story also has weaknesses. Bland (2015) said that one of the weaknesses of the short story lies in its plotline. He said that the plotline of a short story often gets confusing when more than one stories are becoming related since it rarely ever happens. Furthermore, when it is a large series of short stories are written by the same author, the stories tend to get repetitive. Also, Coconi (2017) also pointed out that most short stories lack exposition and begin the narrative from the middle of the story, cutting straight to the chase or get to the main point of the story directly. Very often a short story will have a sudden beginning and an abrupt ending instead of a meaningful 
resolution, focusing more on describing one event and creating a certain emotion, rather than answering questions and solving problems.

To make learning using short stories effective, teachers should carefully select the stories to employ. Pardede (2011) accentuated that story selection is one of the most important roles of the teacher. The lengths of short-stories are quite varying. Therefore, teachers should choose a story that is short enough to handle within course hours. In addition to the length of the text, Hill (as cited in Pardede, 2011) suggested three other basic criteria of choosing the text: (1) the students' needs and abilities; (2) the text's linguistic and stylistic level; and (3) the amount of background information required for a true appreciation of the material.

These criteria importance could be perceived by understanding that the vocabulary and sentence structure of a short story to be studied must be appropriate to the students' mastery level. Short-stories intended for students below the intermediate level which contain slang, archaic, foreign words and allusions, and have sentences mimicking the speech of a particular locality or ignorant people or foreigners should be avoided. Similarly, very long sentences are difficult for students to understand.

Many studies revealed that stories are effective to use to develop learners' vocabulary. have been carried out. Cunningham (2005) reported that reading stories aloud positively affected students' vocabulary acquisition and comprehension. Story reading also provides opportunities for students to learn new words before they have the reading skills necessary to acquire vocabulary independently (Biemiller, 2001). Elley (1989) reported reading a single story three times without any teacher explanation for words increased students' word knowledge considerably Ajideh's (2013) study showed that summarizing short stories significantly improved students' vocabulary. The study of Bell (2001), involving twenty-six elementary students who were divided into control and experimental groups revealed that learners in the experimental group who used short stories outperformed the control group in reading speed.

Although many studies have been carried out to investigate the use of short stories to develop students' vocabulary, studies focusing on students' perceptions are still rare. Pardede's (2010) study did concern about students' perception of the use of short stories in EFL classroom. But the participants were university students. Studies involving primary school students in EFL settings have never been conducted. Considering the meager number of studies investigating students' perception of the use of short stories to develop vocabulary, while the perceptions of students are one of the most important success factors in learning, the present researcher was interested to conduct this study as an attempt to fill in the gap. This study aimed to explore students' perceptions of the use of short stories to develop students' vocabulary in primary schools.

\section{METHOD}

This study used a mixed-methods design in which the researcher "mixed or combined quantitative and qualitative research techniques, methods, approaches, concepts or language into a single study" (Onwegbuzie, 2004). The type employed in this study is the explanatory sequential mixed methods design, which aims at providing relevant information necessary to understand the research problem more efficiently (Pardede, 2018). The study began with quantitative data collection and proceeded with qualitative data collection intended to help explain or elaborate the previously obtained quantitative results 
The participants of the research were 30 sixth graders at the international school Global Sevilla Pulo Mas Campus. The instruments used in the research were a questionnaire (Consist of 20 statements) and an interview guide. The questionnaire was adopted from Mohammed's (2014) work. It consists of 18 statements that had been validated using Cronbach's Alpha test. The result showed that the coefficient of the questionnaire is 0.854 . Thus, it is considered as a reliable instrument.

The questionnaire is organized into three segments. First, the segment which concerns about demographic information. Second, the segment concerning the students' perception of short stories' usefulness, interest, and acceptance of reading short stories. Third, the segment containing some open questions. These data were obtained by asking students to indicate their agreement or disagreement with each statement on a 5-point Liker scale that ranged from strongly agree, score 5 , to strongly disagree, score 1 . The open-ended interview was conducted to obtain qualitative data. The themes that emerge during the interview sessions were coded following the quantitative dimensions from the questionnaire. The writer selected ten students randomly to do the interview session between ten to fifteen minutes.

The quantitative data were analyzed using the descriptive statistical analysis in terms of means and percentages. The quantitative data were combined with the qualitative data and were analyzed descriptively. The Statistical Packages for Social Sciences (SPSS) version 24 was employed in the analysis. To determine the perception levels obtained from the quantitative data analysis, the following criteria were used.

Table 1 .

The Criteria of Perception Level Analysis

\begin{tabular}{ccc}
\hline No & Mean & Criteria \\
\hline 1 & $4.01-5.0$ & Very High \\
2 & $3.01-4.0$ & High \\
3 & $2.01-3.0$ & Medium \\
4 & $1.01-2.0$ & Low \\
5 & $0.5-1.0$ & Very Low \\
\hline
\end{tabular}

\section{FINDINGS AND DISCUSSIONS}

As stated earlier, the students' perception of the use of short stories in vocabulary learning in this study was divided into three indicators, i.e., usefulness, interest, and acceptance. As shown in Table 2, the students' perception of short stories' usefulness in learning vocabulary through short stories is high. The highest mean score in this indicator $(M=4.2)$ concerns with the helpfulness of short stories to develop vocabulary and to improve pronunciation. The lowest mean score is related to their perception of learning vocabulary using short stories gain $(\mathrm{M}=4.0)$, "Short stories facilitate me to learn English". The students agree learning vocabulary using short stories is more efficient and appropriate to develop their vocabulary and also to enhance their pronunciation. This is confirmed by Ghoorchaei's (2016) study which revealed that short stories are very influential in enhancing students' vocabulary learning of Iranian intermediate EFL learners.

The interview indicated the students' belief in the usefulness of short stories in learning. Reading short stories helped them to develop their vocabulary. Furthermore, learning vocabulary through short stories stimulated them to find many vocabularies. They also agreed that short stories facilitated them to develop vocabulary. Webb (2005) stated that productive vocabulary can be addressed as an active process because the 
learners can produce words to express their thoughts to others. Also, active vocabulary refers to output item which the learner can use appropriately in speaking or writing, and it is also called as productive vocabulary.

Table 2

The usefulness of Short Stories in Learning Vocabularies $(N=30)$

\begin{tabular}{|c|c|c|c|c|c|c|c|}
\hline NO & STATEMENTS & $\begin{array}{c}\text { SA } \\
f \\
(\%)\end{array}$ & $\begin{array}{c}A \\
f \\
(\%)\end{array}$ & $\begin{array}{c} \\
f \\
(\%)\end{array}$ & $\begin{array}{c}D \\
f \\
(\%)\end{array}$ & $\begin{array}{c}\text { SD } \\
f \\
(\%)\end{array}$ & Mean \\
\hline 1 & $\begin{array}{l}\text { Short stories motivate me to learn } \\
\text { vocabulary. }\end{array}$ & $9(30)$ & $\begin{array}{c}16 \\
(53)\end{array}$ & $\begin{array}{c}3 \\
(10)\end{array}$ & $\begin{array}{l}2 \\
(7)\end{array}$ & $\begin{array}{c}0 \\
(0)\end{array}$ & 4.0 \\
\hline 2 & Short stories facilitate me to learn English. & $\begin{array}{c}11 \\
(37)\end{array}$ & $\begin{array}{c}8 \\
(27)\end{array}$ & $\begin{array}{c}9 \\
(30)\end{array}$ & $\begin{array}{l}1 \\
(3)\end{array}$ & $\begin{array}{l}1 \\
(3)\end{array}$ & 4.0 \\
\hline 3 & $\begin{array}{l}\text { I learn a lot of vocabulary through short } \\
\text { stories. }\end{array}$ & $\begin{array}{l}10 \\
(33)\end{array}$ & $\begin{array}{l}15 \\
(50)\end{array}$ & $\begin{array}{c}3 \\
(10)\end{array}$ & $\begin{array}{l}2 \\
(7)\end{array}$ & $\begin{array}{c}0 \\
0 \\
(0)\end{array}$ & 4.1 \\
\hline 4 & $\begin{array}{l}\text { Short stories are useful to develop my } \\
\text { vocabulary. }\end{array}$ & $\begin{array}{l}7 \\
(23)\end{array}$ & $\begin{array}{l}18 \\
(60)\end{array}$ & $\begin{array}{c}5 \\
(17)\end{array}$ & $\begin{array}{c}0 \\
0 \\
(0)\end{array}$ & $\begin{array}{c}1 \\
0 \\
(0)\end{array}$ & 4.0 \\
\hline 5 & $\begin{array}{l}\text { When I read short stories, I am better at } \\
\text { improving my pronunciation. }\end{array}$ & $\begin{array}{l}13 \\
(43)\end{array}$ & $\begin{array}{l}11 \\
(37)\end{array}$ & $\begin{array}{c}6 \\
(20)\end{array}$ & $\begin{array}{c}0 \\
0\end{array}$ & $\begin{array}{c}0 \\
(0)\end{array}$ & 4.2 \\
\hline 6 & $\begin{array}{l}\text { Reading short stories help me to learn } \\
\text { vocabulary. }\end{array}$ & $\begin{array}{l}10 \\
(33)\end{array}$ & $\begin{array}{l}17 \\
(57)\end{array}$ & $\begin{array}{c}3 \\
(10)\end{array}$ & $\begin{array}{l}0 \\
(0)\end{array}$ & $\begin{array}{l}0 \\
(0)\end{array}$ & 4.2 \\
\hline 7 & $\begin{array}{l}\text { I always develop my vocabulary through } \\
\text { short stories }\end{array}$ & $\begin{array}{c}6 \\
(20) \\
\end{array}$ & $\begin{array}{l}17 \\
(57)\end{array}$ & $\begin{array}{c}7 \\
(23) \\
\end{array}$ & $\begin{array}{c}0 \\
(0)\end{array}$ & $\begin{array}{c}0 \\
(0)\end{array}$ & 4.0 \\
\hline \multicolumn{7}{|c|}{ Mean Total } & 4.1 \\
\hline
\end{tabular}

As shown in Table 3, the participants perceived that short stories are very interesting to use in learning. Among the seven statements in this table, the one with the highest mean score $(\mathrm{M}=4.2)$ is "I like reading English short stories". The majority $(80 \%)$ of the students strongly agreed and agreed to the statement. Most of them (80\%) also strongly agreed and agreed that learning English through short stories is fun and they were excited to spend their free time to read short stories.

Table 3:

Students' Interest on Reading Short Stories $(N=30)$

\begin{tabular}{|c|c|c|c|c|c|c|c|}
\hline & & SA & A & $\begin{array}{l}\mathrm{N} \\
\mathrm{f}\end{array}$ & $\begin{array}{l}D \\
f\end{array}$ & SD & \\
\hline NO & STATEMENTS & $\begin{array}{c}f \\
(\%)\end{array}$ & $\begin{array}{c}f \\
(\%)\end{array}$ & $\begin{array}{c}f \\
(\%)\end{array}$ & $\begin{array}{c}f \\
(\%)\end{array}$ & $\begin{array}{c}f \\
(\%)\end{array}$ & Mean \\
\hline 8 & I like reading English short stories. & $\begin{array}{c}11 \\
(37)\end{array}$ & $\begin{array}{c}13 \\
(43)\end{array}$ & $\begin{array}{c}6 \\
(20)\end{array}$ & $\begin{array}{c}0 \\
0\end{array}$ & $\begin{array}{c}0 \\
(0)\end{array}$ & 4.2 \\
\hline 9 & I read a short stories every day. & $\begin{array}{c}4 \\
(13)\end{array}$ & $\begin{array}{l}16 \\
(53)\end{array}$ & $6(20)$ & $\begin{array}{c}2 \\
(7)\end{array}$ & $\begin{array}{l}2 \\
(7)\end{array}$ & 3.7 \\
\hline 10 & $\begin{array}{l}\text { I like learning English through short } \\
\text { stories. }\end{array}$ & $\begin{array}{c}9 \\
(30)\end{array}$ & $\begin{array}{l}14 \\
(47)\end{array}$ & $6(20)$ & $\begin{array}{c}1 \\
(3)\end{array}$ & $\begin{array}{l}0 \\
(0)\end{array}$ & 4.0 \\
\hline 11 & $\begin{array}{l}\text { I am excited when I spend free time to } \\
\text { read short stories. }\end{array}$ & $\begin{array}{c}9 \\
(30)\end{array}$ & $\begin{array}{c}11 \\
(37)\end{array}$ & $9(30)$ & $\begin{array}{c}1 \\
(3)\end{array}$ & $\begin{array}{c}0 \\
(0)\end{array}$ & 4.0 \\
\hline 12 & $\begin{array}{l}\text { I feel happy when I am reading a new } \\
\text { story or book. }\end{array}$ & $5(17)$ & $\begin{array}{c}16 \\
(53)\end{array}$ & $7(23)$ & $\begin{array}{c}2 \\
(7)\end{array}$ & $\begin{array}{c}0 \\
(0)\end{array}$ & 3.8 \\
\hline 13 & $\begin{array}{l}\text { Learning English through short stories is } \\
\text { fun. }\end{array}$ & $8(27)$ & $\begin{array}{c}16 \\
(53)\end{array}$ & $5(17)$ & $\begin{array}{c}1 \\
(3)\end{array}$ & $\begin{array}{l}0 \\
(0)\end{array}$ & 4.0 \\
\hline 14 & I like reading short stories at home. & $6(20)$ & $\begin{array}{c}12 \\
(40)\end{array}$ & $8(27)$ & $4(13)$ & $\begin{array}{c}0 \\
(0)\end{array}$ & 3.7 \\
\hline
\end{tabular}


The data obtained from the interview designate that the students like reading short stories to improve their vocabulary. Through short stories, they not only find new vocabulary but also learn many new lessons. Cron (2012) supported this by stating that stories allow us to use our imagination to possibly engender new options and hopefully act with foresight, "to explore our minds of others, as a sort of dress rehearsal for the future.

This finding is in line with Pardede's (2011) finding that the majority of English teachers training students said that, short stories interesting to use both as materials for self-enjoyment and of as components language skill classes. This means that short stories are an interesting tool that can be used to effectively develop vocabulary. Using short stories, students feel more enjoyable and happy in learning vocabulary. It also confirmed Al-Dersi's (2013) idea about the eight strengths of short story use in learning.

The data concerning the students' acceptance of using short stories (Table 4) showed that $80 \%$ of the participants strongly agreed and agreed that short stories are the best tool to develop vocabulary. The other $20 \%$ of the participant was undecided (neutral), and no one disagreed and strongly disagreed. The students agree that reading short stories improve their ability in mastering vocabulary. Using stories provides and supports students' desire to arising their understanding of the story. Stories are motivating, challenging and fun and can help develop positive attitudes (Brewster, Ellis, Girard, 2003). According to Richard and Rodgers (2001) vocabulary is one of the important elements of language proficiency that becomes the basis of how well learners speak, write, listen and read.

Table 4:

Students' Acceptance of Using Short Stories $(N=30)$

\begin{tabular}{|c|c|c|c|c|c|c|c|}
\hline & & SA & $\mathbf{A}$ & $\mathbf{N}$ & $\mathrm{D}$ & SD & \\
\hline NO & STATEMENTS & $\begin{array}{c}f \\
(\%)\end{array}$ & $\begin{array}{c}f \\
(\%)\end{array}$ & $\begin{array}{c}f \\
(\%)\end{array}$ & $\begin{array}{c}f \\
(\%)\end{array}$ & $\begin{array}{c}f \\
(\%)\end{array}$ & Mean \\
\hline 15 & $\begin{array}{l}\text { Short stories are the best tool to develop } \\
\text { my vocabulary. }\end{array}$ & $6(20)$ & $\begin{array}{c}18 \\
(60)\end{array}$ & $6(20)$ & $\begin{array}{c}0 \\
(0)\end{array}$ & $\begin{array}{l}0 \\
0 \\
(0)\end{array}$ & 4.0 \\
\hline 16 & $\begin{array}{l}\text { It helps me understand better if I choose } \\
\text { what I like to read. }\end{array}$ & $\begin{array}{c}11 \\
(37)\end{array}$ & $\begin{array}{c}13 \\
(43)\end{array}$ & $5(17)$ & $\begin{array}{c}0 \\
(0)\end{array}$ & $\begin{array}{c}1 \\
(3)\end{array}$ & 4.1 \\
\hline 17 & $\begin{array}{l}\text { When I do not understand a word, I skip it } \\
\text { and will find the meaning in the dictionary } \\
\text { later. }\end{array}$ & $\begin{array}{c}8 \\
(27)\end{array}$ & $\begin{array}{c}14 \\
(47)\end{array}$ & $\begin{array}{c}4 \\
(13)\end{array}$ & $\begin{array}{c}4 \\
(13)\end{array}$ & $\begin{array}{c}0 \\
(0)\end{array}$ & 3.9 \\
\hline 18 & $\begin{array}{l}\text { When I read, I try to look at the pictures in } \\
\text { the text to understand the meaning. }\end{array}$ & $5(17)$ & $\begin{array}{c}16 \\
(53)\end{array}$ & $6(20)$ & $3(10)$ & $\begin{array}{c}0 \\
(0)\end{array}$ & 3.8 \\
\hline \multicolumn{7}{|c|}{ Mean Total } & 4.0 \\
\hline
\end{tabular}

\section{CONCLUSIONS AND SUGGESTIONS}

Based on the data presentation and interpretation above, it can be concluded that the majority of the respondents have a positive perception of the use of short stories to develop vocabulary. Most of them found short stories useful and interesting so that around $80 \%$ of them were enthusiastic to accept reading short stories for learning. Short stories help them develop vocabulary more easily because the context of the story provides effective clues to get the meaning of unfamiliar words. Since they found short stories interesting, they became active, more motivated, and more enthusiastic in learning 
vocabulary through short stories. This clarified Fahjri's (2018) finding that the students positively perceived the use of short stories in vocabulary development.

Since students have a positive perception of the use of short stories to develop vocabulary, and they find short stories useful and interesting, English teachers need to optimally use these tool to help students learn vocabulary. In doing so, the teachers should keep in mind the need to carefully select the short stories to use so that they meet the students' interests, needs, and abilities.

This study involved only a group of students in the same school. The data were collected through a questionnaire and interview at one point in time only. Consequently, the results may be valid only to students in the same school. To get more comprehensive findings, future studies are recommended to involve a larger number of participants from various schools. Additionally, the use of short stories in EFL learning could be studied using different research designs, such as experimental or action research.

\section{References}

Ajideh, P. (2013). The effect of summarizing short stories on Iranian EFL learners' vocabulary learning. IJSELL, 9(2), 100-113

Al-Dersi, Z.E. (2013). The use of short stories for developing vocabulary of EFL learners. International Journal of English Language \& Translation Studies, 1(1), 72-86, ISSN 2308-5460.

Bell, T. (2001). Extensive reading: Speed and comprehension. The Reading Matrix, Retrieved November 23, 2015, from http://www.readingmatrix.com/articles/bell/.

Biemiller, A. (2001). Teaching vocabulary: Early, direct, and sequential. American Educator, 25, 24-28.

Cunningham, A. E. (2005). Vocabulary growth through independent reading and reading aloud to children. In E. H. Hiebert \& M. L. Kamil (Eds.), Teaching and learning vocabulary: Bringing research to practice. New Jersey: Erlbaum.

Blachowicz, C., \& Fisher, P. (2004). Vocabulary lesson. Educational Leadership, 61(6), 66-69.

Bland, J. (2015). Teaching English for young learners. New York: Bloomsbury Academic.

Brabham, E. G., \& Villaume, S. K. (2002). Vocabulary instruction: Concerns and visions. The Reading Teacher, 56(3), 264-268.

Brewster., Ellis. G., \& Girard, D. (2002). The primary English teacher guided. London: Penguin Longman.

Coconi, A. (2017). Three major differences and similarities between the short story and novel. Accessed On January 5, 2018, from https://penandthepad.com/threebetweenshort-story-novel-8700799.html

Cron, L. (2012). Wired for story. Barkeley: Ten Speed Press.

Elley, W. B. (1989). Vocabulary acquisition from listening to stories read aloud. Reading Research Quarterly, 24(2), 174-187.

Hammer. (2002). How to teach vocabulary. England: Series Editor.

Hornby, A.S. (2000). Oxford advanced learner's dictionary (6th ed.). New York: Oxford University Press.

Mccarthy, M., \& O’Dell, F. (2002). English vocabulary in use advanced. New York. Cambridge University Press.

Nunan, D. (2003). Practical teaching English language teaching. USA: McGraw-Hill Company. 
Onwuegbuzie, A. J., Jiao, Q. G., \& Bostick, S. L. (2004). Library anxiety: Theory, research, and applications. Lanham, MD: Scarecrow Press

Pardede, P. (2018). Mixed Methods Research Designs in EFL. In Pardede, P. (2019). EFL Theory and Practice: Voice of EED UKI (Proceeding of EED Collegiate Forum 2015-2018), pp. 230-243.

Pardede, P. (2011). Using short stories to teach language skills. Journal of English Teaching, 1(1), 14-27. DOI: http://dx.doi.org/10.33541/jet.v1i1.49

Pardede, P. (2010). Short stories use in language skills classes: Students' interest and perception. The Proceeding of the 4th International Seminar 2010: Bringing Linguistics and Literature into EFL Classrooms (pp. 1-17). Salatiga: Satya Wacana Christian University

Parvareshbar, F. \& Ghoorchei, B. (2016). The effect of using short stories on vocabulary learning of Iranian EFL learners. Theory and Practice in Language Studies, 6(7), 1476-1483. DOI: http://dx.doi.org/10.17507/tpls.0607.20

Richard, J.C., \& Rodgers, T.S. (2001). Approaches and methods in language teaching. Cambridge: Cambridge University Press.

Thombury, S. (2004). A course in language teaching: Practice and theory. Cambridge: Cambridge University Press.

Thornbury, S. (2005). How to teach speaking. England: Pearson Education Limited Longman.

Wallace, C. (2007). Vocabulary: The key to teaching English language learners to read. Jacksonville State University.

Webb, S. (2005). Receptive and productive vocabulary learning: The effects of reading and writing on word knowledge. Studies in Second Language Acquisition, 27(1), 33-52.

Williamson, G. (2014). Vocabulary. Retrieved August 6, 2015 from SLTinfo: http://www.sltinfo.com/vocabulary/

Wright, A. (2002). Ways of using stories. Hungary: International Languages Institute. 